\title{
A comparison of 2 evaporative cooling systems on a commercial dairy farm in Saudi Arabia
}

\author{
X. A. Ortiz, ${ }^{\star}$ J. F. Smith, ${ }^{* 1}$ F. Villar, ${ }^{*}$ L. Hall, ${ }^{*}$ J. Allen,† A. Oddy, A. al-Haddad,‡ P. Lyle,§ and R. J. Collier ${ }^{* 2}$ \\ *Department of Animal Science, University of Arizona, Tucson 85719 \\ †Department of Agricultural Sciences, Northwest Missouri State University, Maryville 64468 \\ $\ddagger$ Al Safi Dairy Company, Al-Kharj, 11942, Kingdom of Saudi Arabia \\ §Schaefer Ventilation Equipment, Sauk Rapids, MN 56379
}

\begin{abstract}
Efficacy of 2 cooling systems (Korral Kool, KK, Korral Kool Inc., Mesa, AZ; FlipFan dairy system, FF, Schaefer Ventilation Equipment LLC, Sauk Rapids, $\mathrm{MN})$ was estimated utilizing 400 multiparous Holstein dairy cows randomly assigned to 1 of 4 cooled California-style shade pens (2 shade pens per cooling system). Each shaded pen contained 100 cows (days in milk $=58 \pm 39$, milk production $=56 \pm 18 \mathrm{~kg} / \mathrm{d}$, and lactation $=3 \pm 1$ ). Production data (milk yield and reproductive performance) were collected during 3 mo (June-August, 2013) and physiological responses (core body temperature, respiration rates, surface temperatures, and resting time) were measured in June and July to estimate responses of cows to the 2 different cooling systems. Water and electricity consumption were recorded for each system. Cows in the KK system displayed slightly lower respiration rates in the month of June and lower surface temperatures in June and July. However, no differences were observed in the core body temperature of cows, resting time, feed intake, milk yield, services/cow, and conception rate between systems. The FF system used less water and electricity during this study. In conclusion, both cooling systems ( $\mathrm{KK}$ and $\mathrm{FF}$ ) were effective in mitigating the negative effects of heat stress on cows housed in arid environments, whereas the FF system consumed less water and electricity and did not require use of curtains on the shade structure.
\end{abstract}

Key words: heat stress, evaporative cooling, efficacy, milk yield

\section{INTRODUCTION}

The Kingdom of Saudi Arabia, which constitutes most of the Arab Peninsula, has had a consistent

Received March 24, 2015.

Accepted July 31, 2015.

${ }^{1}$ Deceased.

${ }^{2}$ Corresponding author: rcollier@ag.arizona.edu growth in the production of milk over the last 2 decades. This increase in milk production is the result of improved management practices and investments in facilities and cooling equipment that increase the efficiency of milk production and reduce the effect of environmental stress.

Previous studies have shown that evaporative cooling is effective in reducing thermal stress on lactating dairy cows in climates with high ambient temperatures and low relative humidity $<55 \%$ (Armstrong and Wiersma, 1986; Berman, 2009). Evaporative cooling systems lower the temperature surrounding the cows by injecting water into the air while increasing wind speed to evaporate the water. Lowering the ambient temperature around cows increases the thermal gradient between the cow and the surrounding environment and permits increased heat loss from animals.

The Korral Kool (KK; Korral Kool Inc., Mesa, AZ) system has been previously evaluated under commercial conditions in Saudi Arabia (Ortiz et al., 2010a,b, 2011). The KK system consists of independent reverse chimney units (1.4 $\mathrm{m}$ in diameter) mounted in the middle of the roof at $6-\mathrm{m}$ intervals. These units release high-pressure mist (up to $8.6 \mathrm{~L} / \mathrm{min}$ ) into an airstream, which is ejected through metallic veins, creating a cyclonic motion of the air/mist combination. The water evaporates before hitting the ground, which decreases the air temperature. This system also uses curtains on the west side of the shade to protect cows from the radiation of the sun in the afternoon hours. This is required because the cooling units are fixed and do not move with the shadow as the angle of sunlight changes through the day.

The recently commercialized FlipFan dairy cooling system (FF; Schafer Ventilation Equipment LLC, Sauk Rapids, MN) consists of integrated bays with 4 fans per bay. These fans are spaced at $2-\mathrm{m}$ intervals and are capable of rotating $180^{\circ}$ (east to west) depending on the position of the sun and the wind speed. Each fan has a set of misters that spray up to $7.5 \mathrm{~L} / \mathrm{min}$ per bay of water depending on the environmental conditions (temperature, humidity, and wind speed). Fans 
are $0.91 \mathrm{~m}$ in diameter and use a $3 / 4 \mathrm{hp}$ motor. Fans in this system are mounted in the east side of the roof and are set to aim the opposite direction of the sun. The rotation of the entire system allows cows to move in the direction of the shade with the rotation of the sun, which increases the shaded area for the cows, decreases the time cows spend in the same place, and negates the need for a curtain on the west side of the shade.

Due to the fact that KK system is fixed, cows stand under these units most of the day, which results in a high accumulation urine and feces, which can lead to high moisture in the bedding material. This can be controlled with adequate practices of grooming and sanitation of the lots. However, if lots are not cleaned properly, it could lead to a high incidence of environmental mastitis and other health problems. To determine the efficacy of the 2 systems under intense heat stress, a study was conducted comparing cow performance and physiological responses and consumption of water and electricity of the 2 evaporative cooling systems (FF vs. KK) on a commercial dairy farm located in Saudi Arabia during summer.

\section{MATERIALS AND METHODS}

\section{Experimental Design}

This experiment was conducted at Al Safi Dairy Company, Kingdom of Saudi Arabia, June 1 to August 31,2013 . The dairy is located on the southwest border of the Ad-Dahna desert at latitude $24.15^{\circ} \mathrm{N}$. Minimum, mean, and maximum temperature-humidity index (THI) at this location for this 3-mo period were 68, 80, and 93, respectively. These are all above the thermal threshold for heat stress in high-producing dairy cows (Zimbelman et al., 2009).

Four pens were used to conduct this experiment (2 dry lots per system). Each pen contained a Californiastyle shade and 1 of the 2 cooling systems. Each pen consisted of one California-style barn oriented north to south, which provided $3.8 \mathrm{~m}^{2} /$ cow of shade. Each pen also had feed line shade, which was oriented east to west. All pens were cleaned 4 times/day while cows were in the milking parlor. During this process, all wet dirt was taken out of the shade and placed in the sun, and then replaced with dry dirt. Four hundred multiparous Holstein dairy cows were used in this experiment; 100 cows were randomly assigned to each dry lot (DIM $=58 \pm 39 \mathrm{~d}$, milk production $=56 \pm 18 \mathrm{~kg} / \mathrm{d}$, and lactation $=3 \pm 1$ ). Production data (milk and feed intake) and reproductive data (AI and pregnancy checks after the $0900 \mathrm{~h}$ milking) were collected daily throughout the study. Physiological measurements were taken for 6 consecutive days in the months of June and July. After the first period of physiological measurements finished in the month of June, cows in 2 randomly selected pens (one pen per system) switched to the alternate cooling system, whereas the cows in other 2 pens remained with their respective treatments. Cows that switched pens were moved on July 1 and remained in those pens until the end of the experiment. Cows in the other 2 untouched pens were used to identify any reproductive difference between treatments. During the first week of July, both cooling systems received a maintenance service to make sure cows would get the maximum cooling provided by each system. Visual inspection of the pens was also performed at nighttime to make sure the systems were performing correctly on both treatments.

All cows were milked in the same parlor 4 times/day at $0200,0800,1400$, and $2000 \mathrm{~h}$. All cows were cooled with KK units in the holding pen. Fans and soakers were used while cows were being milked, and exit lane showers wetted the back of the cows when they exited the milking parlor. Milk production records per cow were collected every day using Alpro milking software (De Laval International AB, Tumba, Sweden).

Cows were fed 6 times/day TMR ration; feed refusals were collected and weighed once per day. Two different rations were fed to the cows during the development of this experiment (Table 1). The first diet was fed from June 1 to July 27. The second diet was fed from July 28 until the end of the experiment (August 31). Cows on both treatments ( $\mathrm{KK}$ and $\mathrm{FF}$ ) always received the same diet. Pen feed intake was calculated by subtracting the total feed refused by each pen to the total feed fed to each pen. These values were recorded every day for further feed intake comparison.

To identify differences in the reproductive performance of cows on both systems, individual cow data (AI date, pregnancy check, and abortions) were collected and recorded using Dairy Comp 305 (Valley Agricultural Software, Tulare, CA).

Temperature and humidity were measured and recorded by 8 weather stations located at cow height in different locations around the farm. Each weather station contained a temperature and humidity sensor (Hobo U23 pro V2, Onset Computer Corp., Bourne, MA) and a solar radiation shield (M-RSA, Onset Computer Corp.). Weather stations were set to measure and record ambient temperature and relative humidity at 15-min intervals. The THI values were calculated based on the average temperature and humidity data obtained from the weather stations and defined by the following equation (Ravagnolo and Misztal, 2000):

$$
\begin{aligned}
& \mathrm{THI}=[(1.8 \times \mathrm{Tdb})+32]-(0.55-0.0055 \times \mathrm{RH}) \\
& \times(1.8 \times \mathrm{Tdb}-26)
\end{aligned}
$$


Table 1. Ingredients and chemical composition of $\operatorname{diets}^{1}$

\begin{tabular}{lcc}
\hline Item & Diet 1 & Diet 2 \\
\hline Ingredient, \% of DM & \\
Corn silage & 23.97 & 22.70 \\
Alfalfa hay & 21.97 & 22.03 \\
Corn (steam flaked) & 25.30 & 25.37 \\
Soymeal & 2.66 & 2.40 \\
Cottonseed & 5.33 & 5.34 \\
Bypass protein & 3.99 & 4.27 \\
Wheat bran & 1.33 & 1.07 \\
Energizer & 1.33 & 1.34 \\
Corn wet fiber & 7.99 & 9.35 \\
Buffer & 1.07 & 1.07 \\
Early milking premix & 2.40 & 2.40 \\
Soybean hulls & 1.33 & 1.34 \\
Barley hay & 1.33 & 1.34 \\
Chemical analysis & & \\
DM, \% & 26.49 & 26.45 \\
CP, \% & 17.46 & 17.46 \\
ADF, \% & 17.31 & 17.31 \\
NDF, \% & 27.91 & 27.91 \\
Fat, \% & 3.5 & 3.5 \\
NE, Mcal/kg of DM & 1.75 & 1.75 \\
\hline Diet 1 was fed from & $D 18 t 2$ & \\
\hline
\end{tabular}

${ }^{1}$ Diet 1 was fed from June 1 to July 27. Diet 2 was fed from June 28 to August 31.

where $\mathrm{Tdb}=$ temperature dry bulb in degrees Celsius, and $\mathrm{RH}=$ relative humidity in percentage.

After cows were distributed to their respective pen, 25 cows in each pen (50 cows/system) were randomly selected to track core body temperature (CBT), surface temperature, respiration rates, and locomotion activity for $6 \mathrm{~d}$. Intravaginal data loggers (Hobo U12, $\pm 0.25^{\circ} \mathrm{C}$, Onset Computer Corp.) were set to measure and record $\mathrm{CBT}$ of cows at 5-min intervals. These data loggers were attached to blank continuous intravaginal drug release devices (Pfizer Animal Health, New York, NY). Surface temperatures and respiration rates were recorded every day at 0700, 1200, and $1600 \mathrm{~h}$. Surface temperatures were obtained with an infrared thermometer (Fluke 568, Fluke Corporation, Everett, WA) by measuring the surface temperature of the rump, tail, head, and shoulder of cows. Respirations rates were obtained by counting flank movements for $15 \mathrm{~s}$ and multiplying this number by 4 . Surface temperatures and respiration rates were collected on resting animals under the shade while being cooled. Surface temperature readings were collected at a distance of less than 8 $\mathrm{m}$. Locomotion activity was measured by using position sensors (Hobo Pendant G, \pm 0.105 g, Onset Computer Corp.) that were placed on the interior of the right rear leg of each cow and set to record data at 1-min intervals for $6 \mathrm{~d}$.

To record the water and electricity usage for each cooling system, water, and electrical meters were placed in each pen at the beginning of the experiment. These data were collected each morning during the entire duration of the project.

A grid calorimetric analysis of both cooling systems was developed to measure the cooled area under each system (Figure 1). This analysis was conducted on 2 consecutive days at $1400 \mathrm{~h}$ after the physiological measurements were collected and while the cows were being milked in the months of June and July. Systems ran for 2 consecutive hours, and 25 temperature/humidity (Hobo U23 pro V2, $\pm 0.21^{\circ} \mathrm{C}$, Onset Computer Corp.) and 15 wind speed sensors (S-WSA-M003, $\pm 1.1 \mathrm{~m} / \mathrm{s}$, Onset Computer Corp.) were set to measure and record data at 30 -s intervals. Wind speed sensors were connected to 4 weather micro stations (H21-002, Onset Computer Corp.). Sensors were pleased at $1 \mathrm{~m}$ above the ground according to the grid distribution explained by a previous study (Ortiz et al., 2010a). Because fans in the FF cooling system rotate depending on the sun angle (time of day), sensors were placed depending on the position of the shadow of the shade, that way sensors always received the cooling effect of the system. Ambient temperature data were analyzed using Surfer software (Surfer 8, Golden Software Inc., Golden, CO) to create calorimetric graphs of both systems.

The convective heat transferred was calculated by the following formula (ASHRAE, 1966):

$$
\mathrm{Q}_{\mathrm{cv}}=\mathrm{hA}_{\mathrm{cv}} \mathrm{V}^{1 / 2}\left(\mathrm{~T}_{\mathrm{s}}-\mathrm{T}_{\mathrm{a}}\right)
$$

where $\mathrm{Q}_{\mathrm{cv}}=$ conductive coefficient; $\mathrm{h}=$ heat transfer coefficient; $\mathrm{A}_{\mathrm{cv}}=$ surface area available for convection; $\mathrm{V}^{1 / 2}=$ wind speed to $1 / 2$ exponent; $\left(\mathrm{T}_{\mathrm{s}}-\mathrm{T}_{\mathrm{a}}\right)=$ difference between the surface temperature and ambient temperature.

The conductive coefficient used in this analysis was of $14.06 \mathrm{kcal} / \mathrm{h}$ per ${ }^{\circ} \mathrm{C}$ ). The area available for convection was $80 \%$ of $1 \mathrm{~m}^{2}$. For this analysis, we used the individual wind speed and ambient temperature data point of each sensor placed in the grid under the shade. The mean surface temperature for each month was used as $\mathrm{T}_{\mathrm{s}}$.

\section{Statistical Analysis}

Data in this experiment were analyzed by using a mixed model of SAS (version 9.3, SAS Institute Inc., Cary, NC). Core body temperature, milk yield, respiration rates, surface temperatures, and resting time were analyzed according to the following model:

$$
\begin{gathered}
\mathrm{Y}_{\mathrm{ijk}}=\mu+\mathrm{T}_{\mathrm{i}}+\mathrm{P}_{\mathrm{j}}+\mathrm{C}_{\mathrm{k}}\left(\mathrm{P}_{\mathrm{j}}\right)+\mathrm{D}_{\mathrm{l}}+\mathrm{H}_{\mathrm{m}} \\
+\mathrm{T}_{\mathrm{i}} \mathrm{H}_{\mathrm{m}}+\mathrm{e}_{\mathrm{ijklm}},
\end{gathered}
$$


where $Y_{\mathrm{ijk}}=$ an individual data point, $\mu=$ overall mean, $\mathrm{T}_{\mathrm{i}}=$ fixed effect of treatment $(\mathrm{i}=1$ to 2$), \mathrm{P}_{\mathrm{j}}$ $=$ random effect of pen $(\mathrm{j}=1$ to 4$), \mathrm{C}_{\mathrm{k}}\left(\mathrm{P}_{\mathrm{j}}\right)=$ random effect of cow within pen $(\mathrm{k}=1$ to 25$), \mathrm{D}_{1}=$ random effect of day ( $\mathrm{l}=1$ to 6$), \mathrm{H}_{\mathrm{m}}=$ fixed effect of time $(\mathrm{m}$ $=1$ to 24$)$, and $\mathrm{e}_{\mathrm{ijklm}}=$ residual error.

To analyze CBT treatment by time interactions, $3 \mathrm{~h}$ per milking were taken out of the analysis $(2-4,8-10$, 14-16, and 20-22) for both treatments. This was done to account for a difference in $1 \mathrm{~h}$ between the milking times of the 4 pens.

Feed intake was analyzed using the mixed procedure with treatment as fixed effect and with pen and week as random effects. Milk yield was also analyzed with the mixed procedure with treatment as fixed effect and with cow within pen and week as random effects. Ambient temperature, wind speed, and convective heat transferred were analyzed using the mixed procedure with fixed treatment and repeated grid position. The chi-squared analysis was used to evaluate conception rates of cows for both treatments.

Different covariance structures were used in the system and the one with lower Akaike information criterion was chose as the better fit for this model. Treatment effects for all the variables were tested by the LSMEANS option and were declared significant at $P<0.05$.

\section{RESULTS}

Mean 24-h ambient temperature, relative humidity, and THI for the month of June are described in Figure 2. Mean climatic conditions for the month of June were ambient temperature $32.9^{\circ} \mathrm{C}$, relative humidity $16.6 \%$, and THI of 76.3 .

Milk production and feed intake during this experiment is described in Table 2. No difference was observed between treatments and the milk production of cows during this experiment. Cows on both systems reported an average milk production of $52 \mathrm{~kg} /$ cow per d (Table 2). Additionally, no significant difference was observed in the weekly milk production of cows under both treatments (Figure 3). Average feed intake of cows for both cooling systems is shown in Table 2. No differences in feed intake were detected between systems in either month of the study, and cows displayed an average feed intake of $53 \mathrm{~kg} /$ cow per d (Table 2). Figure 4 shows the weekly feed intake of cows during this experiment for both treatments. A significant treatment effect was found in wk $1(P<0.05$, Figure 4$)$.

Mean respiration rate and surface temperature for the month of June are described in Table 3. Treatment by time interactions of both cooling systems on the respiration rates of cows for the month of June are de-

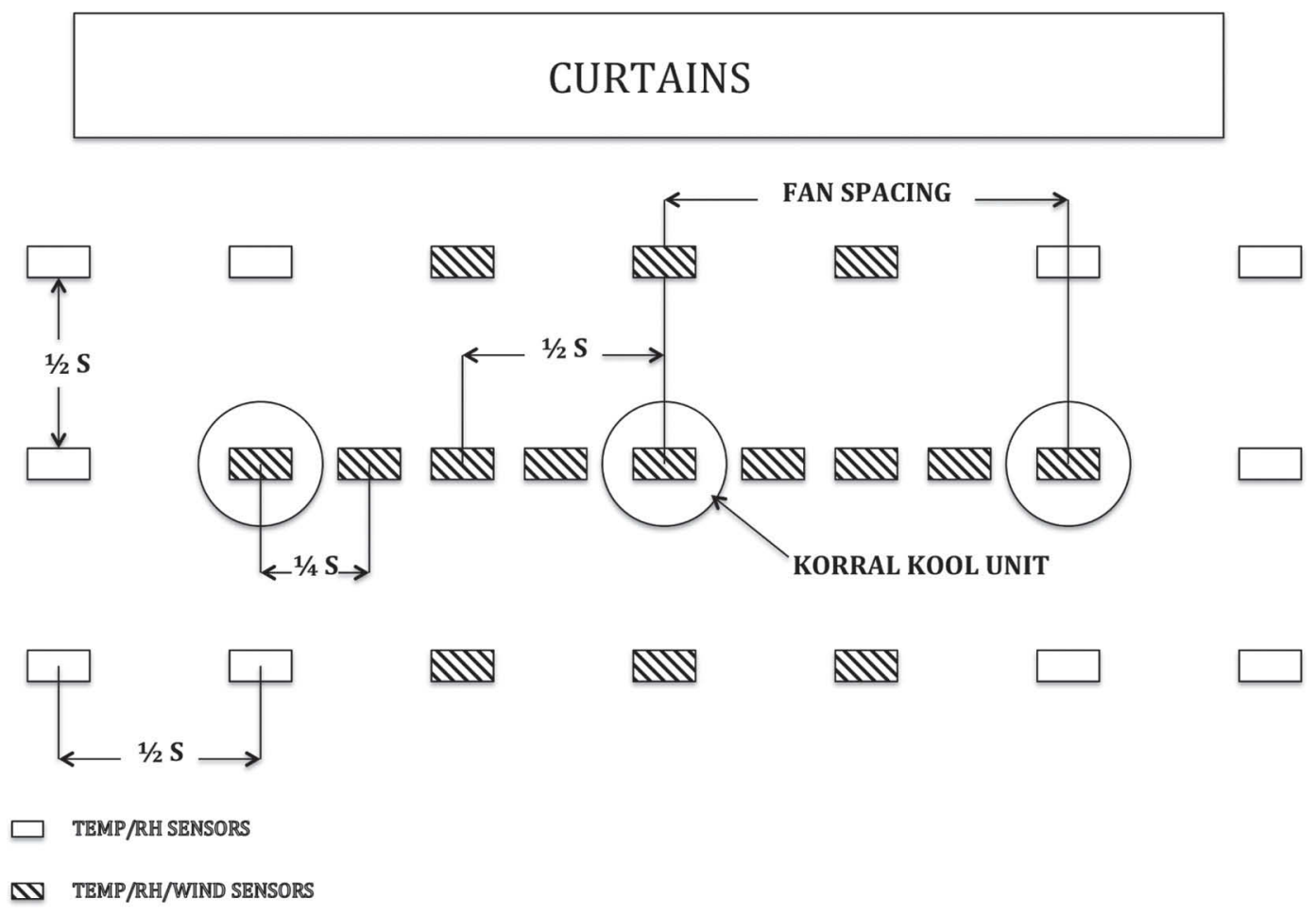

Figure 1. Calorimetric grid for the distribution of sensors under both cooling systems: Korral Kool (Korral Kool Inc., Mesa, AZ) and FlipFan (Schaefer Ventilation Equipment LLC, Sauk Rapids, MN). Temp = temperature; RH = relative humidity; S = distance. 


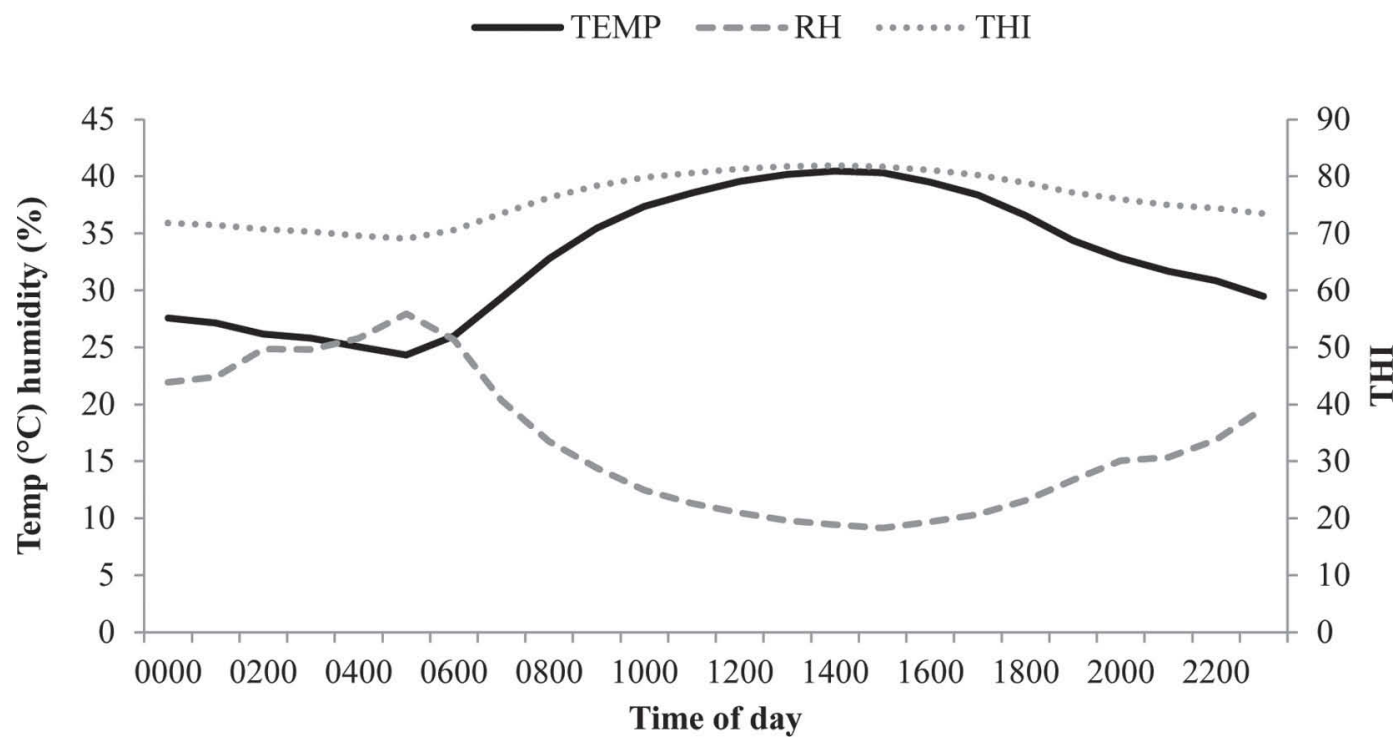

Figure 2. Average ambient temperature (TEMP), relative humidity (RH), and temperature-humidity index (THI) by hour (June). SEM: $\mathrm{TEMP}=0.15, \mathrm{RH}=0.24$, and $\mathrm{THI}=0.11$.

scribed in Table 4. Respiration rates of cows under the 2 systems varied but were slightly lower in cows housed under the KK system compared with the FF system $(P<0.05$, Table 3). Although cows in KK displayed lower respiration rates than cows in $\mathrm{FF}$ at 0700 and $1600 \mathrm{~h}(P<0.05$, Figure 4$)$, respiration rates were not significant for cows in KK compared with FF at $1200 \mathrm{~h}$.

Mean surface temperature was not significantly different between systems in the month of June (Table 3). The surface temperature of cows in the FF system was higher at 0700 and $1200 \mathrm{~h}$, but the surface temperature of cows in FF was lower than cows for FF at $1600 \mathrm{~h}(P$ $<0.05$, Table 5).

The values for mean CBT of cows for both cooling systems for the month of June are reported in Table 3. A significant treatment by time interaction was observed between both cooling systems in the month of June $(P<0.05$, Figure 5). The greatest difference between the systems was observed at $0500 \mathrm{~h}$ when the

Table 2. Effect of 2 cooling systems on mean DMI, milk yield, and services per cow (June to August) ${ }^{1}$

\begin{tabular}{lrrr}
\hline & \multicolumn{2}{c}{ System } & \\
\cline { 2 - 3 } Measurement & \multicolumn{1}{c}{ FF } & \multicolumn{1}{c}{ KK } & SEM \\
\hline Feed intake, kg/d per cow & 53.29 & 53.21 & 0.36 \\
Milk production, kg/cow per d & 52.28 & 52.20 & 0.34 \\
Services per conception & 1.70 & 1.81 & 0.08 \\
Conception rate, \% & 35.48 & 41.13 & \\
\hline
\end{tabular}

${ }^{1} \mathrm{KK}=$ Korral Kool (Korral Kool Inc., Mesa, AZ); FF = FlipFan (Schaefer Ventilation Equipment LLC, Sauk Rapids, MN).
CBT of KK system was lower to the FF system (38.43 and $38.77^{\circ} \mathrm{C}$, respectively, $P<0.05$, Figure 5).

Climatic conditions and THI for the month of July are described in Figure 6. Average temperature during this month was $34.8^{\circ} \mathrm{C}$, relative humidity $23.23 \%$, and THI of 78.46. The climatic conditions in June and July were significantly different $(P<0.05$, Figures 2 and 6$)$ for temperature, relative humidity, and THI. However, as Figures 2 and 6 show, the THI in both months were above the THI threshold of 68 at all hours, which would suggest that these cows were always under a stressful environment if no additional cooling was provided.

We also observed no difference in the mean resting time of cows housed under both cooling systems in the months of June and July (Table 3). Cows had a mean resting time of 12.81 and $12.71 \mathrm{~h} / \mathrm{d}$ for FF and KK, respectively, for June (Table 3), and cows on both systems had a mean resting time above $14 \mathrm{~h} / \mathrm{d}$ in July despite the fact that ambient conditions were more stressful in July than in June $(P<0.05$, Figures 2 and 6$)$.

No difference was observed in the mean respiration rate between the 2 cooling systems in July (Table 3 ). Treatment by time interactions of both cooling systems on the respiration rates of cows for the month of July are described in Table 4. A significant treatment by time interaction was observed between respiration rates and the type of cooling systems. The KK system showed lower respiration rates in the morning hours $(0700 \mathrm{~h})$, whereas the FF system showed lower respiration rates in the afternoon hours $(1600 \mathrm{~h})$. No difference was observed between at $1200 \mathrm{~h}(P<0.05$, Table 4$)$. 


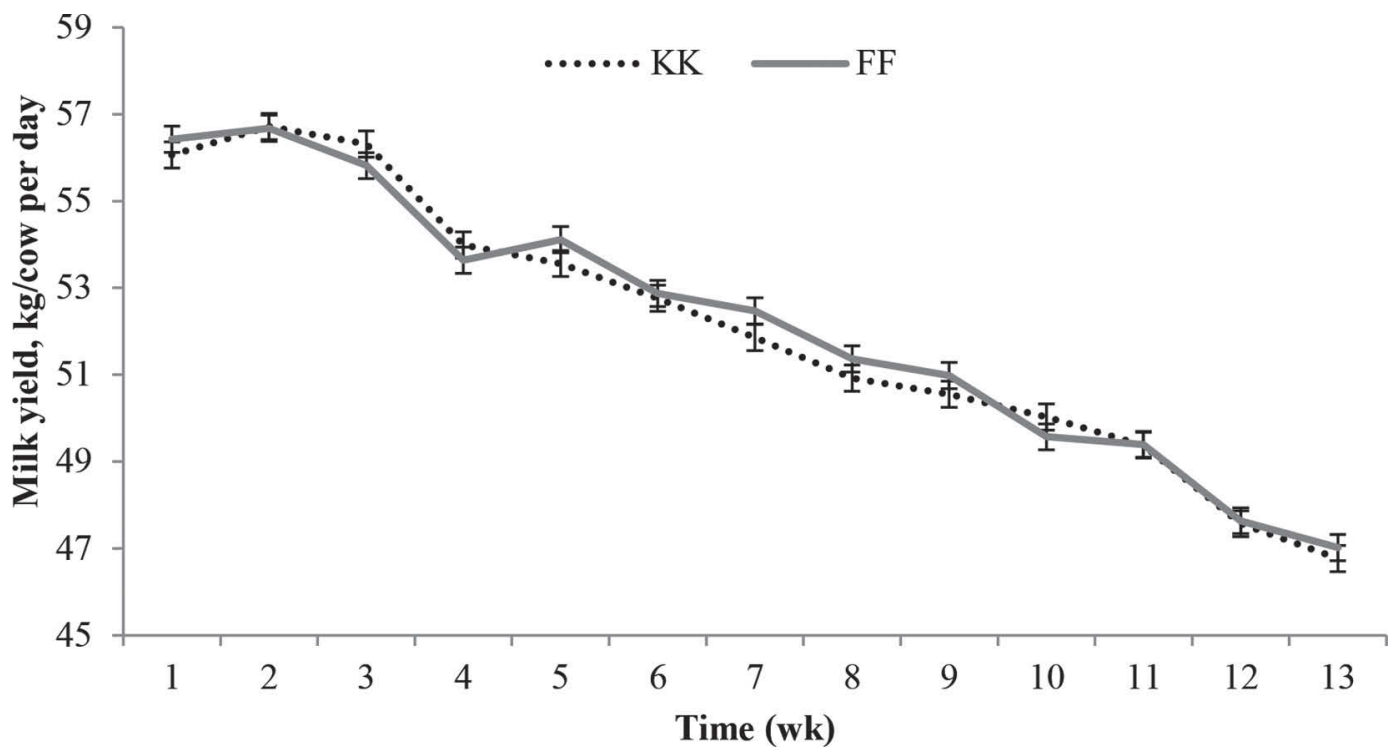

Figure 3. Weekly milk production of cows during 3 mo for both treatments KK and FF. KK = Korral Kool (Korral Kool Inc., Mesa, AZ); $\mathrm{FF}=$ FlipFan (Schaefer Ventilation Equipment LLC, Sauk Rapids, MN). SEM (error bars) =0.3.

A treatment by time interaction was observed with lower surface temperatures for the KK system at 0700 and $1200 \mathrm{~h}$. No difference was observed between sys- tems in the surface temperature of cows at $1600 \mathrm{~h}(P$ $<0.05$, Table 5). The mean surface temperature was significantly different between both systems for the

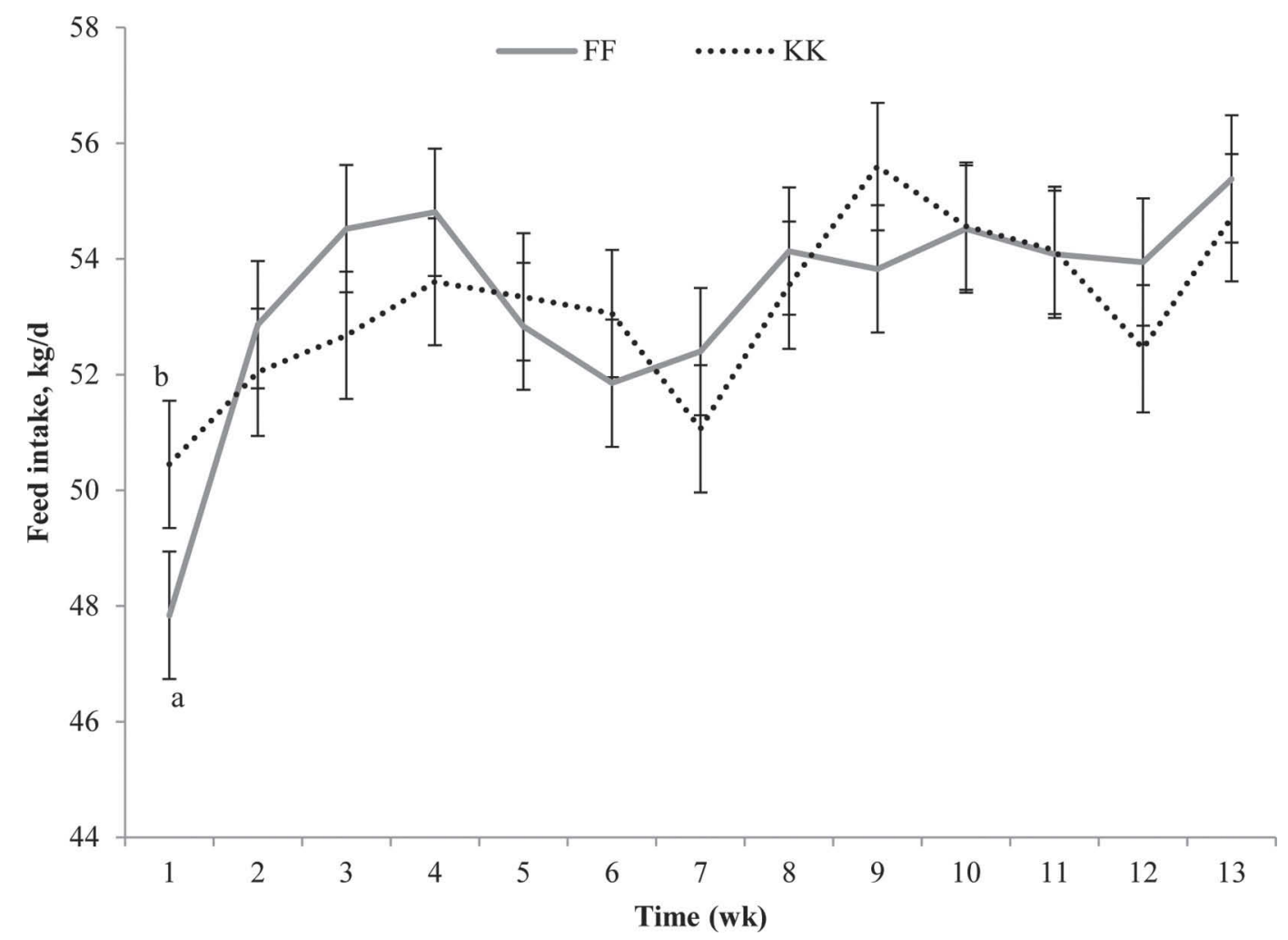

Figure 4. Average weekly feed intake. KK = Korral Kool (Korral Kool Inc., Mesa, AZ); FF = FlipFan (Schaefer Ventilation Equipment LLC, Sauk Rapids, MN). Letters (a, b) indicate treatment interaction: $P<0.05$; SEM $=1.1$. 


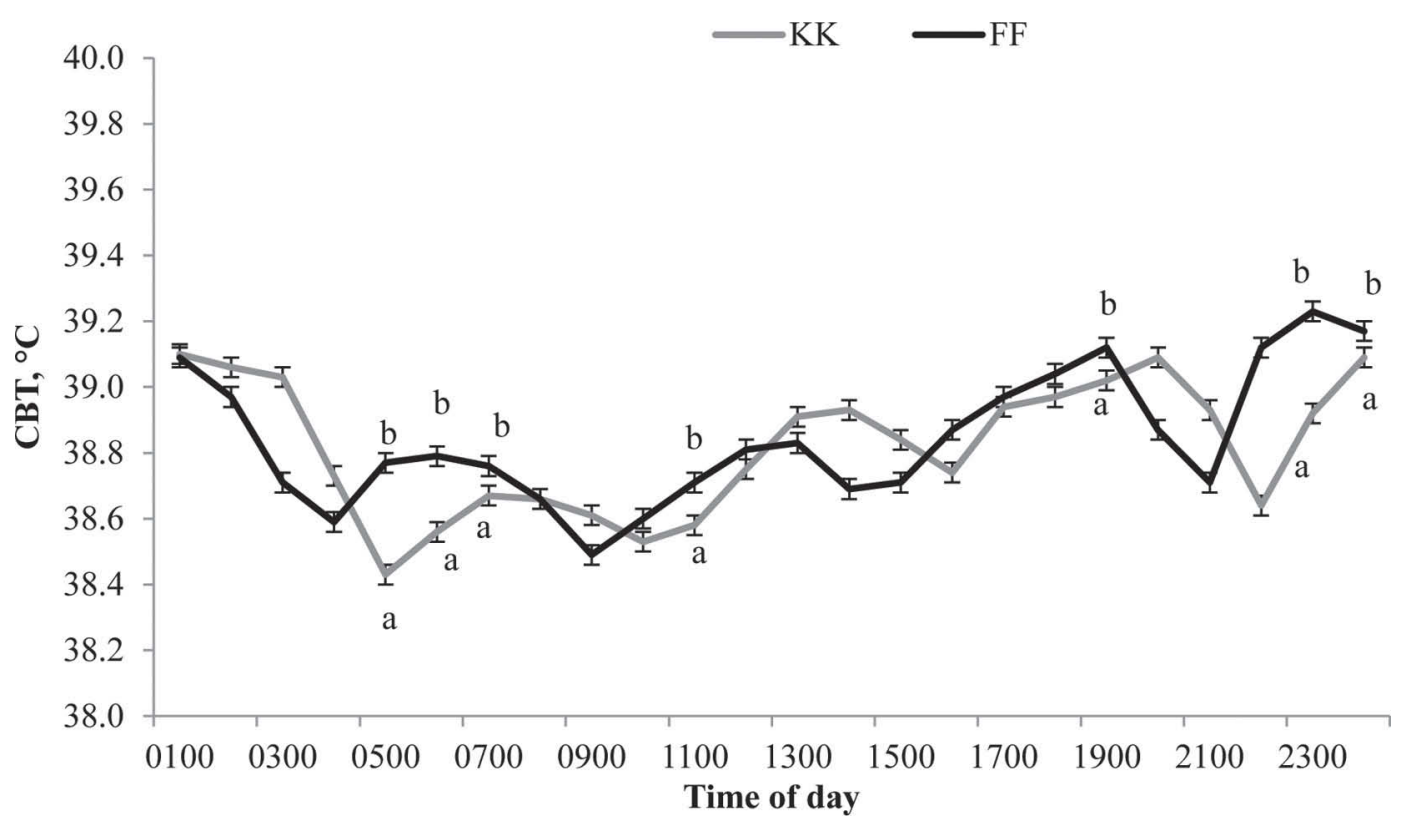

Figure 5. Continuous core body temperature (CBT) of cows in 2 different cooling systems in the month of June. KK = Korral Kool (Korral Kool Inc., Mesa, AZ); FF = FlipFan (Schaefer Ventilation Equipment LLC, Sauk Rapids, MN). Letters (a, b) indicate treatment $\times$ time interaction: $P<0.05 ; \mathrm{SEM}=0.03$

Table 3. Effect of 2 cooling systems on core body temperature (CBT), respiration rates, surface temperature, and resting time in the months of June and July ${ }^{1}$

\begin{tabular}{|c|c|c|c|c|}
\hline \multirow[b]{2}{*}{ Month } & \multirow[b]{2}{*}{ Measurement } & \multicolumn{2}{|c|}{ System } & \multirow[b]{2}{*}{ SEM } \\
\hline & & FF & KK & \\
\hline \multirow[t]{4}{*}{ June } & $\mathrm{CBT},{ }^{\circ} \mathrm{C}$ & 38.84 & 38.82 & 0.02 \\
\hline & Respiration rate, breaths/min & $58.36^{\mathrm{a}}$ & $56.44^{\mathrm{b}}$ & 0.88 \\
\hline & Surface temperature, ${ }^{\circ} \mathrm{C}$ & 31.43 & 30.94 & 0.48 \\
\hline & Resting time, $\mathrm{h}$ & 12.81 & 12.71 & 0.19 \\
\hline \multirow[t]{4}{*}{ July } & $\mathrm{CBT},{ }^{\circ} \mathrm{C}$ & 38.80 & 38.80 & 0.03 \\
\hline & Respiration rate, breaths/min & 60.00 & 60.24 & 0.97 \\
\hline & Surface temperature, ${ }^{\circ} \mathrm{C}$ & $33.36^{\mathrm{a}}$ & $32.37^{\mathrm{b}}$ & 0.25 \\
\hline & Resting time, $\mathrm{h}$ & 14.28 & 14.41 & 0.19 \\
\hline
\end{tabular}

a,b Treatment interaction: $P<0.05$.

${ }^{1} \mathrm{KK}=$ Korral Kool (Korral Kool Inc., Mesa, AZ); FF = FlipFan (Schaefer Ventilation Equipment LLC, Sauk Rapids, MN)

Table 4. Effect of cooling systems on respiration rates (breaths $/$ min) by hour for the months of June and July ${ }^{1}$

\begin{tabular}{lllll}
\hline & & \multicolumn{2}{c}{ System } & \\
\cline { 3 - 4 } Month & Time, h & FF & KK & \multirow{2}{*}{ SEM } \\
\hline \multirow{2}{*}{ June } & 0700 & $55.92^{\mathrm{a}}$ & $52.08^{\mathrm{b}}$ & 1.2 \\
& 1200 & 59.28 & 60.36 & 1.1 \\
\multirow{3}{*}{ July } & 1600 & $59.84^{\mathrm{a}}$ & $56.92^{\mathrm{b}}$ & 1.1 \\
& 0700 & $63.63^{\mathrm{a}}$ & $60.33^{\mathrm{b}}$ & 1.2 \\
& 1200 & 61.03 & 60.28 & 1.2 \\
& 1600 & $55.35^{\mathrm{a}}$ & $60.10^{\mathrm{b}}$ & 1.3 \\
\hline
\end{tabular}

\footnotetext{
${ }^{\mathrm{a}, \mathrm{b}}$ Treatment interaction: $P<0.05$.

${ }^{1} \mathrm{KK}=$ Korral Kool (Korral Kool Inc., Mesa, AZ); FF = FlipFan (Schaefer Ventilation Equipment LLC, Sauk Rapids, MN).
}

Table 5. Effect of cooling systems on surface temperatures $\left({ }^{\circ} \mathrm{C}\right)$ by hour for the months of June and July ${ }^{1}$

\begin{tabular}{lllll}
\hline & & \multicolumn{2}{c}{ System } & \\
\cline { 3 - 4 } Month & Time, h & FF & KK & \multirow{2}{*}{ SEM } \\
\hline \multirow{2}{*}{ June } & 0700 & 31.01 & 30.38 & 0.33 \\
& 1200 & $31.81^{\mathrm{a}}$ & $30.33^{\mathrm{b}}$ & 0.32 \\
\multirow{3}{*}{ July } & 1600 & $30.45^{\mathrm{a}}$ & $32.12^{\mathrm{b}}$ & 0.32 \\
& 0700 & $33.34^{\mathrm{a}}$ & $32.26^{\mathrm{b}}$ & 0.29 \\
& 1200 & $33.19^{\mathrm{a}}$ & $30.74^{\mathrm{b}}$ & 0.29 \\
& 1600 & 33.55 & 34.11 & 0.31 \\
\hline
\end{tabular}

${ }^{\mathrm{a}, \mathrm{b}}$ Treatment interaction: $P<0.05$.

${ }^{1} \mathrm{KK}=$ Korral Kool (Korral Kool Inc., Mesa, AZ); FF = FlipFan (Schaefer Ventilation Equipment LLC, Sauk Rapids, MN). 

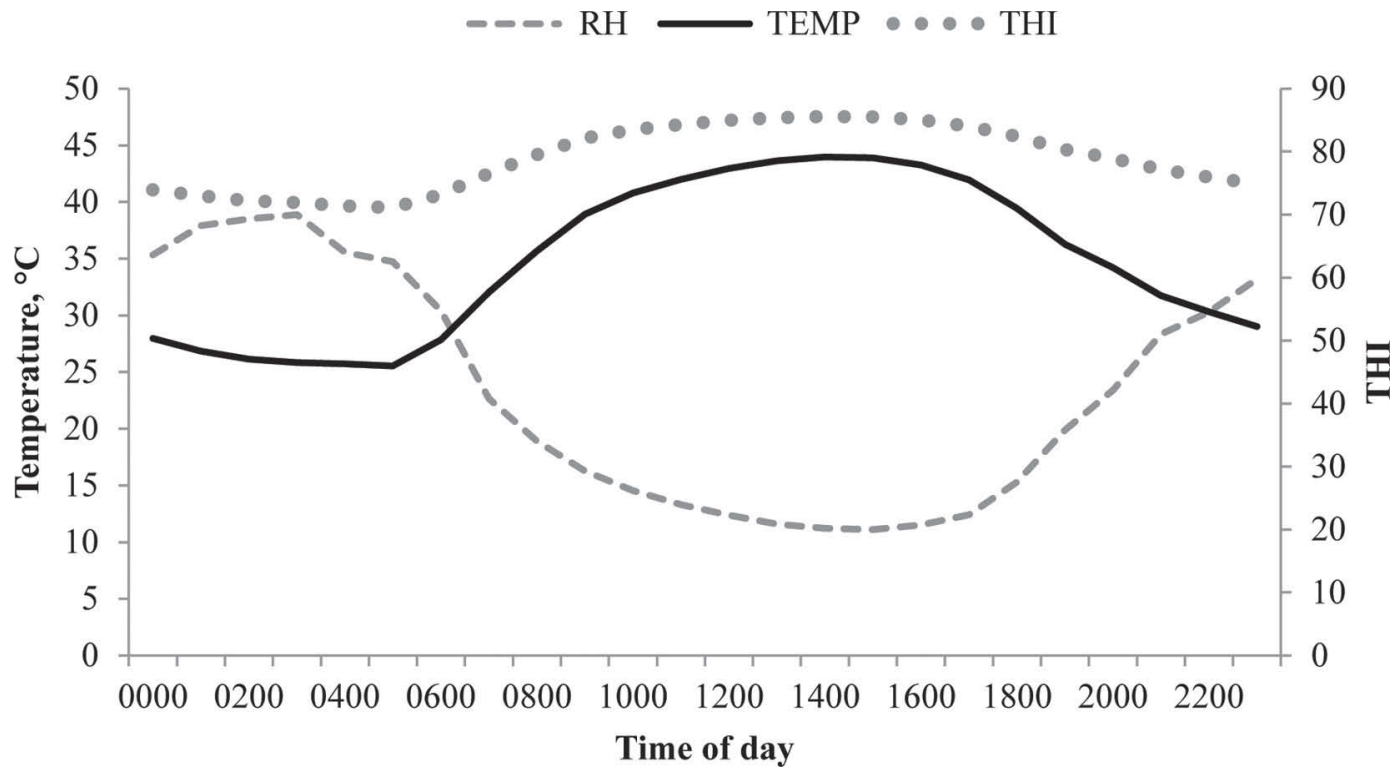

Figure 6. Average ambient temperature (TEMP), relative humidity (RH), and temperature-humidity index (THI) by hour (July). SEM: $\mathrm{TEMP}=0.07, \mathrm{RH}=0.11$, and $\mathrm{THI}=0.05$.

month of July $(P<0.05$, Table 3$)$, with lower surface temperatures reported for the KK system $\left(32.37^{\circ} \mathrm{C}\right)$.

Mean CBT of cows in both cooling systems for the month of July is showed in Table 3. Even though no significant difference was observed between treatments on the mean CBT of cows, a significant treatment by time interaction was observed at $1100 \mathrm{~h}(P<0.05$, Figure 7). The biggest difference between the 2 systems was observed at $1100 \mathrm{~h}(P<0.05$, Figure 7$)$. No differences between cooling systems were observed in the conception rate of cows or the services/cow (Table 2).

Water and electric utilization per cooling systems is described in Table 6. No significant difference was observed in the water utilization of both systems in the month of June. However, FF showed lower water usage compared with the KK system for the month of July $(P$

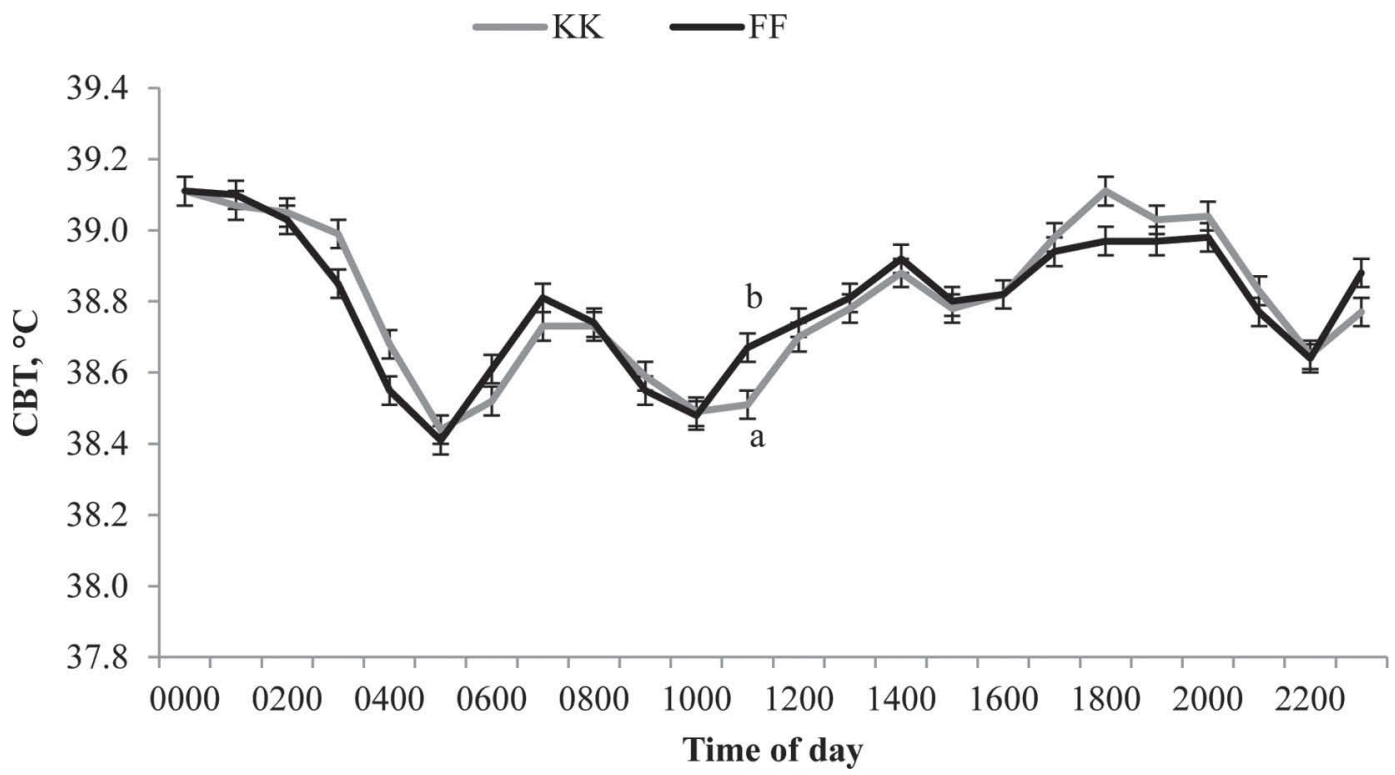

Figure 7. Continuous core body temperature (CBT) of cows in 2 different cooling systems in the month of July. KK = Korral Kool (Korral Kool Inc., Mesa, AZ); FF = FlipFan (Schaefer Ventilation Equipment LLC, Sauk Rapids, MN). Letters (a, b) indicate treatment $\times$ time interaction: $P<0.05 ; \mathrm{SEM}=0.03$ 
Table 6. Water and electricity usage of both cooling systems in the months of June and July ${ }^{1}$

\begin{tabular}{llccc}
\hline \multirow{2}{*}{ Month } & & \multicolumn{2}{c}{ System } & \\
\cline { 3 - 4 } & Measurement & \multirow{2}{*}{ FF } & \multirow{2}{*}{ KK } & \multirow{2}{*}{ SEM } \\
\hline \multirow{2}{*}{ June } & Water usage, $\mathrm{L} /$ cow per d & 376.26 & 356.85 & 9.9 \\
\multirow{2}{*}{ July } & Electricity usage, $\mathrm{kW} /$ cow per d & $4.12^{\mathrm{a}}$ & $4.57^{\mathrm{b}}$ & 0.13 \\
& Water usage, $\mathrm{L} / \mathrm{cow}$ per d & $365.40^{\mathrm{a}}$ & $390.73^{\mathrm{b}}$ & 6.5 \\
& Electricity usage, $\mathrm{kW} /$ cow per d & $3.97^{\mathrm{a}}$ & $4.59^{\mathrm{b}}$ & 0.08 \\
\hline
\end{tabular}

a,b Treatment interaction: $P<0.05$.

${ }^{1}$ KK $=$ Korral Kool (Korral Kool Inc., Mesa, AZ); FF = FlipFan (Schaefer Ventilation Equipment LLC, Sauk Rapids, MN).

$<0.05$, Table 6). The FF system showed lower electric usage compared with the KK system in both June and July $(P<0.05$, Table 6$)$.

Sensors in the calorimetric analysis covered $108 \mathrm{~m}^{2}$ in each system. Average ambient temperature under the shade for the FF cooling system in the month of June was $25.86^{\circ} \mathrm{C}$ and for the $\mathrm{KK}$ system $24.04^{\circ} \mathrm{C}$ (Table 7). Average ambient temperatures for the month of July were 24.02 and $28.79^{\circ} \mathrm{C}$ for $\mathrm{KK}$ and FF systems, respectively (Table 7 ). The KK system showed lower temperatures in both months compared with the FF system $(P<0.05$, Table 7$)$.

From this calorimetric analysis, we observed that the lowest temperatures for the KK system were located between units within a barn (Figures 8 and 9, respectively). For the FF system, the lowest temperatures were observed in a radius of $1.5 \mathrm{~m}$ around the fans (Figures 10 and 11, respectively).

The KK system showed higher temperatures in 1 unit compared with the other 2 units analyzed in the grid in June and July (Figures 8 and 9). This difference in temperature was the result of plugged misters, which decreased the flow of water and compromised the cooling effect of this system.

Wind speed for each system is described in Table 7 . The FF system produced higher wind speeds compared with the KK system in June and July $(P<0.05$, Table 7 ). In July, wind speeds for both systems were higher than wind speeds recorded for the month of June. This is simply due to the fact that the settings for wind speed and water use were increased for the month of July for both systems due to the higher ambient heat loads experienced in July compared with June (Figures 6 and 2 , respectively).

The convective heat transfer for both systems is described in Table 7. The FF systems showed higher convective heat transferred compared with the KK system for the month of June $(P<0.05$, Table 7$)$. This difference between systems is the result of higher wind speed obtained by the FF system $(P<0.05$, Table $7)$. The KK system showed higher convective heat flow compared with the FF system in the month of July $(P<0.05$, Table 7$)$. The higher convective heat transferred for the KK system is the result of lower air temperatures compared with the FF system $(P<0.05$, Table 7).

\section{DISCUSSION}

The CBT of cows is the best indicator of environmental heat load because it is very sensible to climate fluctuations. The normal CBT of cows under thermoneutral conditions is $38.6^{\circ} \mathrm{C}$ (Dukes, 1947). The average CBT of cows in this experiment for both systems in June and July was above this value, indicating that even with the cooling systems employed the cows were

Table 7. Ambient temperature, wind speed, and convective heat transferred of FF and KK cooling systems ${ }^{1}$

\begin{tabular}{|c|c|c|c|c|}
\hline \multirow[b]{2}{*}{ Month } & \multirow[b]{2}{*}{ Measurement } & \multicolumn{2}{|c|}{ System } & \multirow[b]{2}{*}{ SEM } \\
\hline & & FF & KK & \\
\hline \multirow[t]{3}{*}{ June } & Ambient temperature, ${ }^{\circ} \mathrm{C}$ & $25.86^{\mathrm{a}}$ & $24.04^{\mathrm{b}}$ & 0.06 \\
\hline & Wind speed, $\mathrm{m} / \mathrm{s}$ & $2.18^{\mathrm{a}}$ & $1.34^{\mathrm{b}}$ & 0.03 \\
\hline & Convection, $\mathrm{kcal} / \mathrm{h}$ per $\mathrm{m}^{2}$ & $183.08^{\mathrm{a}}$ & $126.86^{\mathrm{b}}$ & 11.28 \\
\hline \multirow[t]{3}{*}{ July } & Ambient temperature, ${ }^{\circ} \mathrm{C}$ & $28.79^{\mathrm{a}}$ & $24.02^{\mathrm{b}}$ & 0.20 \\
\hline & Wind speed, $\mathrm{m} / \mathrm{s}$ & $4.17^{\mathrm{a}}$ & $3.97^{\mathrm{b}}$ & 0.06 \\
\hline & Convection, $\mathrm{kcal} / \mathrm{h}$ per $\mathrm{m}^{2}$ & $152.64^{\mathrm{a}}$ & $240.15^{\mathrm{b}}$ & 20.16 \\
\hline
\end{tabular}

a,b Treatment interaction: $P<0.05$.

${ }^{1} \mathrm{KK}=$ Korral Kool (Korral Kool Inc., Mesa, AZ); FF = FlipFan (Schaefer Ventilation Equipment LLC, Sauk Rapids, MN). 

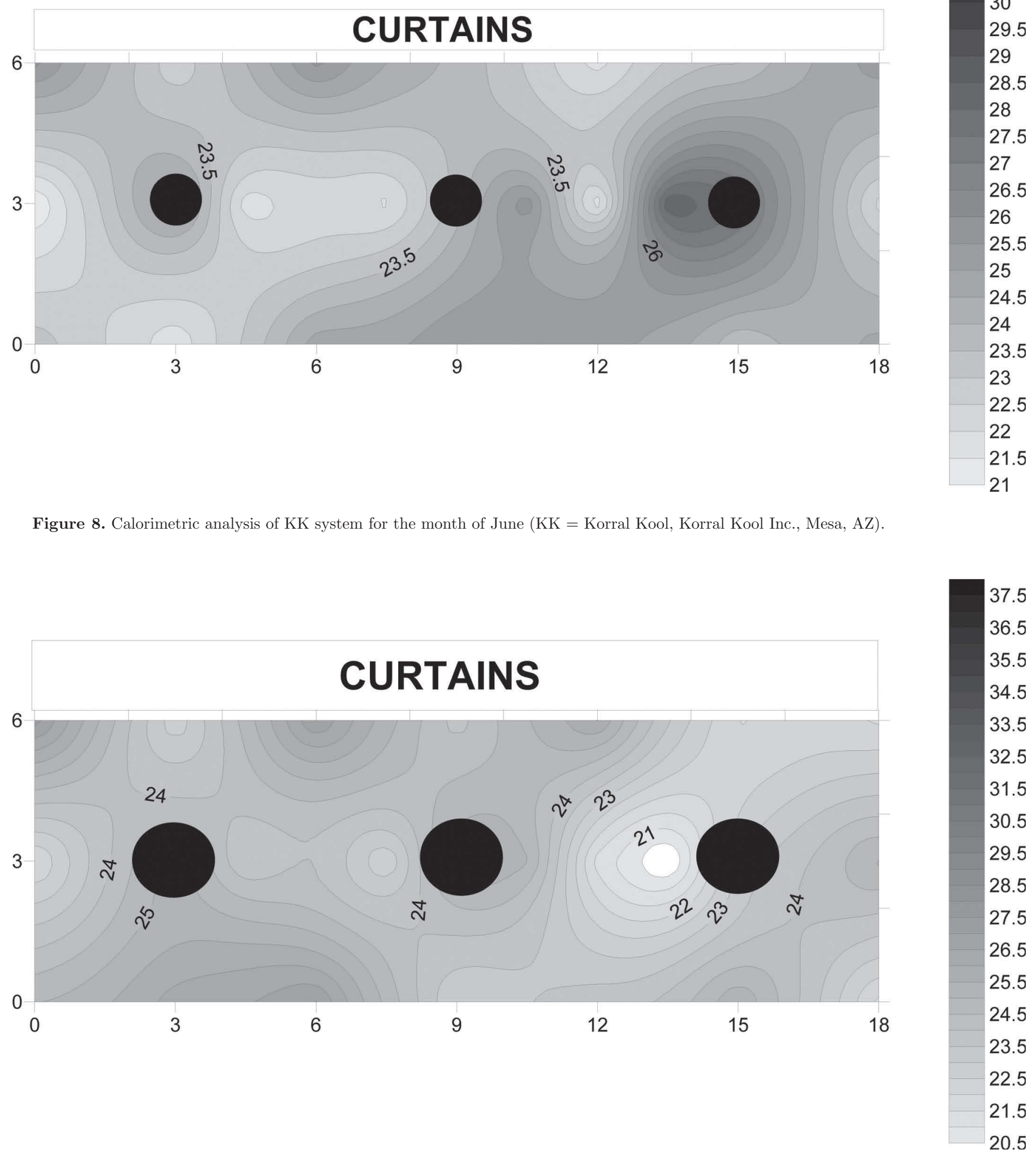

Figure 9. Calorimetric analysis of KK system for the month of July (KK = Korral Kool, Korral Kool Inc., Mesa, AZ). 


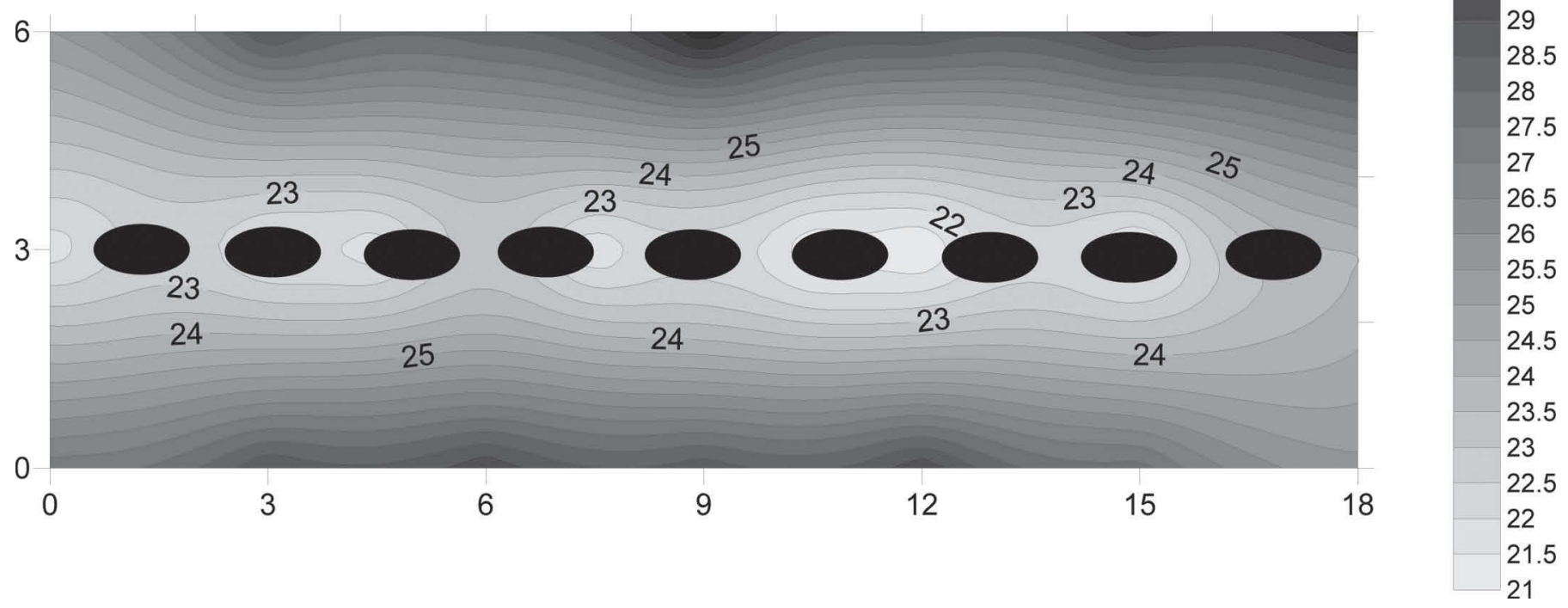

Figure 10. Calorimetric analysis of FF system for the month of June (FF = FlipFan, Schaefer Ventilation Equipment LLC, Sauk Rapids, $\mathrm{MN})$.

6

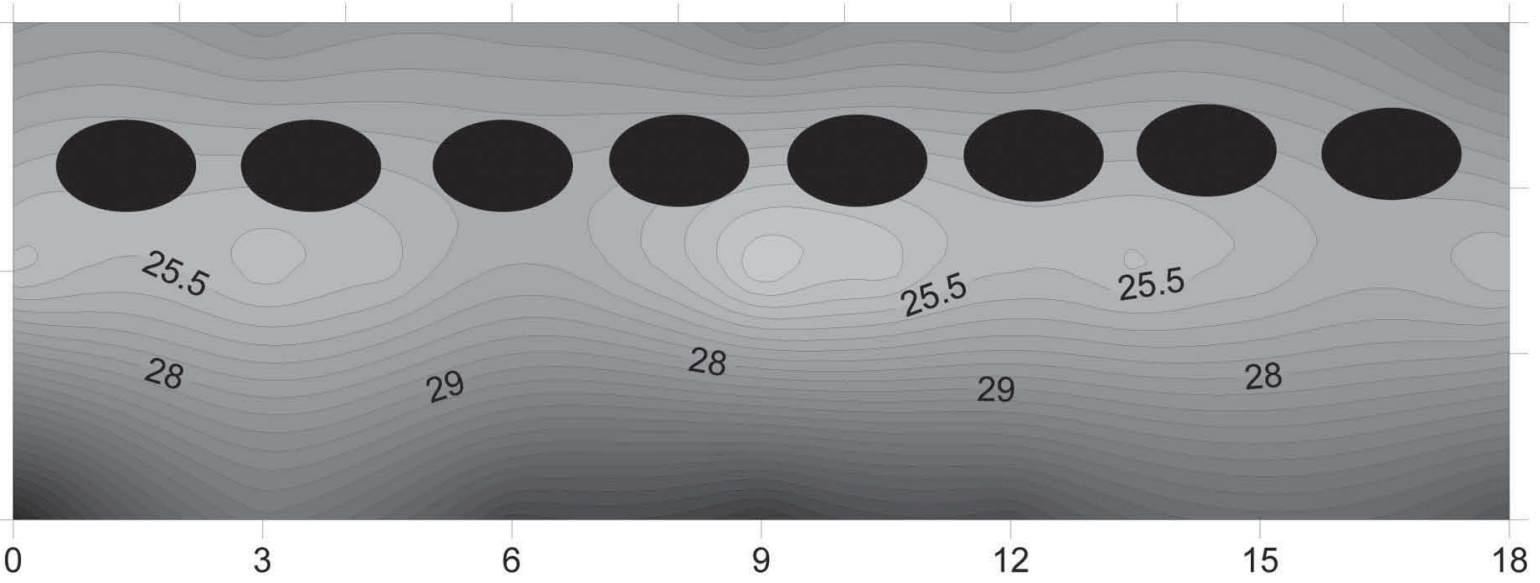

37.5

36.5

35.5

34.5

33.5

32.5

31.5

30.5

29.5

28.5

27.5

26.5

25.5

24.5

23.5

22.5

21.5

20.5

Figure 11. Calorimetric analysis of FF system for the month of July (FF = FlipFan, Schaefer Ventilation Equipment LLC, Sauk Rapids, MN). 
still experiencing daily increases in CBT. The CBT of cows in the month of July were lower compared with the CBT of cows in the month of June. This may be the result of a reduction in the metabolic heat produced by cows with lower milk yield $(55.37$ and $51.78 \mathrm{~kg} /$ cow per $\mathrm{d}$ for June and July, respectively, $P<0.05$ ). However, cows housed under both cooling systems were producing more than $50 \mathrm{~kg} / \mathrm{d}$ of milk.

Average surface temperature for both systems during this experiment remained below the threshold for heat stress $\left(35^{\circ} \mathrm{C}\right.$; Berman et al., 1985). The heat stress threshold for respiration rate is 60 breaths/min, which is half maximal (Berman et al., 1985). Respiration rates in the month of June remained under 60 for both systems; however, in the month of July the respiration rates of cows under both systems were above the threshold in the morning and $1200 \mathrm{~h}$.

Feed intake and milk yield of animals did not differ between the 2 cooling treatments; however, it has been shown that the milk production and feed intake of cows are compromised at THI as low as 68 (Zimbelman et al., 2009). During this experiment, the ambient THI (outside the shade) at peak hours was 81 in June and 85 in July. This means that the external climatic conditions should have affected the performance of cows in both treatment groups. However, the THI at cow level inside the shades at the hottest hours of the day ranged between 68 and 78 for KK and between 68 and 81 for the FF system for the month of June and between 67 and 74 for KK and between 69 and 82 for the FF system for the month of July. We therefore conclude that both systems reduced but did not completely eliminate the negative effects of heat stress on milk yield and feed intake.

Resting time of cows for both systems in July (14.41 and $14.28 \mathrm{~h} / \mathrm{d}$ for $\mathrm{KK}$ and FF, respectively) were higher than the resting times registered in June (12.71 and $12.81 \mathrm{~h} / \mathrm{d}$ for $\mathrm{KK}$ and $\mathrm{FF}$, respectively). A high correlation was found between resting time and the CBT of cows (Allen et al., 2015). This difference in resting time may be explained by higher CBT of cows in June (38.82 and $38.84^{\circ} \mathrm{C}$ for $\mathrm{KK}$ and $\mathrm{FF}$, respectively) compared with July $\left(38.80\right.$ and $38.80^{\circ} \mathrm{C}$ for $\mathrm{KK}$ and $\mathrm{FF}$, respectively).

Previous research has demonstrated the negative effects of heat stress on reproduction in cows (De Rensis and Scaramuzzi, 2003; García-Ispierto et al., 2006), these negative effects start at a THI of 55 and are more evident at higher THI (García-Ispierto et al., 2006). In this experiment, no difference was observed between treatments. However, it is important to highlight how both systems appear to have improved the reproductive performance of cows given the estimations that cows at these THI levels have an average conception rate of 25.7\% (García-Ispierto et al., 2007).

In modern dairying, water and electric utilization are becoming important factors when decisions are made about the cooling system used on a dairy farm. The FF system used less water in the month of July compared with the KK system (365 vs. $390 \mathrm{~L} / \mathrm{d}$, respectively). This difference agrees with previous estimations of water utilization of the KK system (305 to $460 \mathrm{~L} / \mathrm{d}$; Burgos et al., 2007). Although this level of water utilization is high, it must be balanced with the cost of shipping in milk from more distant dairy-producing regions. Despite a reduction in water usage observed in the FF system, the growing limitations in water availability in some parts of the world reduce the sustainability of these 2 systems long term. The development of cooling abatement techniques that take into consideration not only the effectiveness of the system, but also the amount of resources needed to accomplish this process, is urgently needed. An alternative for this kind of environments could be the use of passively cooled barns and the use of conductive cooling (Ortiz et al., 2015).

The FF system used less electricity than the KK system in both months. This was accomplished by using smaller motors $(3 / 4 \mathrm{hp})$ compared with the 5 -hp motors in the KK system. During this study, the FF system was more efficient in reducing the negative effect of heat stress (feed intake, milk production, and reproduction) by using less water and electricity than the KK system.

Even though the ambient temperatures inside the shade of the KK system were lower, it was observed that the temperature under this system was not constant throughout the cooled area. It is hypothesized that these microclimates within the shade will result in dominant cows displacing submissive cows out of the cooler areas (Ryan et al., 1992).

The grid calorimetric analysis shown in Figures 8 and 10 for the month of June and Figures 9 and 11 for the month of July demonstrated that the FF system maintained a more consistent environment inside the grid evaluated than the KK system. However, the average temperature inside the grid area was lower for the KK system. The variability seen in the temperature pattern for the KK system also demonstrates the importance of a maintenance plan of cooling systems for their adequate operation.

During the month of June, the performance of the FF system as measured by changes in CBT was exceeded by the KK system. Based on the CBT data, the difference between systems was more evident at night. By visual inspection of cows, it was observed that most cows spent the night dispersed in the pen and not under 
the cooling system. This behavior may be explained by the accumulation of water in the ground forcing cows to look for a dry place to rest or the fact that the hot metal roof would be radiating heat down on the cows during nighttime hours. In addition, because radiant heat moves at the speed of light, cows can radiate heat to the cooler night sky, which is another reason they are more likely to move out from under the shades during nighttime hours. In the month of July, the CBT of cows under the FF system did not increase during the night, which may be the result of higher evaporation of water due to higher ambient temperatures.

Thus, no major differences were observed in body temperature, feed intake, or milk yield between these cooling systems under these environmental and management conditions during June and July, the hottest months of the year for this location. The study would have been more powerful with a control treatment, but this was not possible in the commercial setting. It is important to understand the difficulties in producing milk under these climatic conditions. Results from this experiment demonstrated that both cooling systems do an excellent job cooling down cows and maintaining high productivity, and in this study the Schaefer FF dairy cooling system matched the KK performance with lower water and electricity consumption.

\section{ACKNOWLEDGMENTS}

This project was supported financially by Schaefer Ventilation Equipment. The authors thank all the staff and personnel at Al Safi Dairy Company that assisted in this experiment. The authors thank John F. Smith for his leadership and dedication to the dairy industry. His work and unconditional support made him an excellent mentor and colleague, but above all, his kindness and good heart made him a great person and friend.

\section{REFERENCES}

Allen, J. D., L. W. Hall, R. J. Collier, and J. F. Smith. 2015. Effect of core body temperature, time of day, and climate conditions on behavioral patterns of lactating dairy cows experiencing mild to moderate heat stress. J. Dairy Sci. 98:118-127.
Armstrong, D. V., and F. Wiersma. 1986. An update on cow cooling methods in the west. Am. Soc. Agric. Eng., St. Joseph, MI. Microfiche collection (86):4034.

ASHRAE. 1966. Fundamentals and Equipment. Guide and Data Book. ASHRAE, New York, NY.

Berman, A. 2009. Predicted limits for evaporative cooling in heat stress relief of cattle in warm conditions. J. Anim. Sci. 87:3413-3417.

Berman, A., Y. Folman, M. Kaim, M. Mamen, Z. Herz, D. Wolfenson, A. Arieli, and Y. Graber. 1985. Upper critical temperatures and forced ventilation effects for high-yielding dairy cows in a subtropical climate. J. Dairy Sci. 68:1488-1495.

Burgos, R., L. J. Odens, R. J. Collier, L. H. Baumgard, and M. J. VanBaale. 2007. Case Study: Evaluation of different cooling systems in lactating heat-stressed dairy cows in a semi-arid environment. Prof. Anim. Sci. 23:546-555.

De Rensis, F. D., and R. J. Scaramuzzi. 2003. Heat stress and seasonal effects on reproduction in the dairy cow-A review. Theriogenology 60:1139-1151.

Dukes, H. H. 1947. The Physiology of Domestic Animals. 6th ed. Comstock Publishing Company Inc., Ithaca, NY.

García-Ispierto, I., F. López-Gatius, G. Bech-Sabat, P. Santolaria, J. L. Yániz, C. Nogareda, F. De Rensis, and M. López-Béjar. 2007. Climate factors affecting conception rate of high producing dairy cows in northeastern Spain. Theriogenology 67:1379-1385.

García-Ispierto, I., F. López-Gatius, P. Santolaria, J. L. Yániz, C. Nogareda, M. López-Béjar, and F. De Rensis. 2006. Relationship between heat stress during the peri-implantation period and early fetal loss in dairy cattle. Theriogenology 65:799-807.

Ortiz, X. A., J. F. Smith, B. J. Bradford, J. P. Harner, and A. Oddy. 2010a. A comparison of the effects of 2 cattle-cooling systems on dairy cows in a desert environment. J. Dairy Sci. 93:4955-4960.

Ortiz, X. A., J. F. Smith, B. J. Bradford, J. P. Harner, and A. Oddy. 2010b. Effects of running time of a cattle-cooling system on core body temperature of cows on dairy farms in an arid environment. J. Dairy Sci. 93:4949-4954.

Ortiz, X. A., J. F. Smith, B. J. Bradford, J. P. Harner, and A. Oddy 2011. Effect of complementation of cattle cooling systems with feedline soakers on lactating dairy cows in a desert environment. J. Dairy Sci. 94:1026-1031.

Ortiz, X. A., J. F. Smith, F. Rojano, C. Y. Choi, J. Bruer, T. Steele, N. Schuring, J. Allen, and R. J. Collier. 2015. Evaluation of conductive cooling of lactating dairy cows under controlled environmental conditions. J. Dairy Sci. 98:1759-1771.

Ravagnolo, O., and I. Misztal. 2000. Genetic component of heat stress in dairy cattle, parameter estimation. J. Dairy Sci. 83:2126-2130.

Ryan, D., M. Boland, E. Kopel, D. Armstrong, L. Munyakazi, R. Godke, and R. Ingraham. 1992. Evaluating two different evaporative cooling management systems for dairy cows in a hot, dry climate. J. Dairy Sci. 75:1052-1059.

Zimbelman, R. B., R. P. Rhoads, M. L. Rhoads, G. C. Duff, L. H. Baumgard, and R. J. Collier. 2009. A re-evaluation of the impact of temperature humidity index (THI) and black globe humidity index (BGHI) on milk production in high producing dairy cows. Pages 158-168 in Proc. Southwest Nutr. Manage. Conf. Tempe, AZ, The University of Arizona, Tucson. 